https://doi.org/10.31516/2410-5333.059.05

УДК 378.011.3 - 051:373.5.091.33-027.22

\title{
M. Shlenova
}

Candidate of Philological Sciences, Associate Professor of the Document science and Ukrainian language Department, National Aerospace University, Kharkiv, Ukraine

m.shleneva@khai.edu

https://orcid.org/0000-0003-4297-6872

\section{GAMIFICATION AS A TOOL FOR INCREASING THE LEANRING EFFICIENCY OF FUTURE LIBRARIANS}

The article deals with gamification mechanisms to increase staff performance and diversify the mechanisms of professional learning to improve the training of future librarians. In this the article we conducted a survey among studentsinterns of the university library on their attitude to gamification in the learning process. The results revealed that respondents mostly positively evaluate gamification as a tool in the process of acquiring professional knowledge. The gamification tool is used to increase the effectiveness of learning and to facilitate the adaptation of students to the professional activities of librarians. The results of the research can be used to identify the effects of the gamification tool on improving the efficiency of training processes and the professional growth of staff in various fields.

Keywords: gamification, library, efficiency, training, information.

\section{М. Г. Шленьова}

кандидат філологічних наук (PhD), доцент кафедри документознавства та української мови, Національний аерокосмічний університет ім. М. Є. Жуковського «Харківський авіаційний інститут», м. Харків, Україна

\section{ГЕЙМІФІКАЦІЯ ЯК ІНСТРУМЕНТ ПІДВИЩЕННЯ ЕФЕКТИВНОСТІ НАВЧАННЯ МАЙБУТНІХ БІБЛІОТЕКАРІВ}

Актуальність теми. Значні обсяги професійної інформації потрібно засвоювати надзвичайно швидко, щоб опанувати професію та стати справжнім професіоналом. Для цього в процесі професійного навчання слід використовувати спеціальні інструменти, які мають на меті підвищення ефективності адаптації майбутніх співробітників до професійного середовища та мотивацію персоналу до кар'єрного зростання.

Мета статті - аналіз використання механізмів гейміфікації для підвищення ефективності роботи персоналу та врізноманітнення методик професійного навчання для поліпшення підготовки майбутніх бібліотекарів.

Методологія. У статті подано опитування студентів-стажерів університетської бібліотеки, у якому вони висловили своє ставлення до використання гейміфікації в процесі навчання. В опитуванні взяли участь студенти спеціальності 029 «Інформаційна, бібліотечна та архівна справа» XAl, 50 студентів $(m=17, f=33)$.

1 This work is licensed under a Creative Commons Attribution-NonCommercial-ShareAlike 4.0 International License. 
Результати. Під час дослідження було розглянуто основні праці сучасних українських учених (Н. Кравець, О. Дідякова, Н. Волкова, В. Бугаєва, О. Макаревич та ін.), присвячені використанню гейміфікації в освітніх та професійних процесах, включно з досвідом зарубіжних колег (M. Barber, A. Faria, D. Clark, L. Sheldon). Результати опитування студентів-стажерів показали, що респонденти переважно позитивно оцінюють гейміфікацію як інструмент у процесі здобуття професійних знань.

Новизна. Інструмент гейміфікації використовується для підвищення ефективності навчання. Розроблена корпоративна гра покликана полегшити адаптацію студентів-стажерів до професійної діяльності бібліотекарів.

Практичне значення. Ключові концепції цієї розвідки можуть бути використані в наукових дослідженнях, зокрема у виявлених впливах інструменту гейміфікації на підвищення ефективності навчальних процесів та професійного зростання персоналу в різних сферах. Ефективність цього інструменту доведена західними вченими, котрі використовували його, зокрема, як корпоративну гру для підвищення ефективності службовців бізнескомпаній.

Висновки. У результаті пілотний проєкт пройшов усі стадії впровадження, реалізовано завдання підвищення рівня знань і зміцнено корпоративну культуру працівників бібліотеки та студентів-стажерів. Автор дослідження дійшов висновку, що до таких проєктів слід залучати працівників бібліотек, щоб урізноманітнити навчання новими технологіями, які сприяють ефективності робочого процесу. Студентам-стажерам ця гра допомагає зануритися в атмосферу бібліотеки, зрозуміти основні принципи та механізми роботи.

Ключові слова: гейміфікація, бібліотека, ефективність, навчання, інформація.

Formulation of the issue. In modern society, there is a growing interest in innovative methods and approaches to quality knowledge development and their application in practice. The amount of information in the world increases, new algorithms, and solutions are developed and implemented in new activities. It should be noted that the human brain in the globalization century processes much more information than the human brain 100 years ago, and does it way faster. The brain interprets information and focuses on a single object from 9 to 14 seconds, which indicates the need to use mechanisms that can help absorb large flows of information in a minimal period. This will allow to optimize and revise approaches to staff training methods to increase efficiency. Libraries also use online resources, visualization, educational video content, interactive platforms, statistic resources, simulators, and other tools to improve staff performance and familiarize students with the profession of a librarian. Among these tools, more and more attention is paid to gamification, as a tool with proven effectiveness that can increase staff performance and diversify the mechanisms of learning and professional information. 
Analysis of recent researches and publications. The topic of gamification in the educational process and training is actively studied by modern Ukrainian scientists. N. Kravets (Kravets, 2017) analyzed the basic concepts of gamification proposed by various experts, in particular, by Kevin Werbach and Gabe Zichermann based on publications that study the theory and practice of gamification, the basic principles of using its methods in business and education. O. Didiakova (Didiakova, 2018) described the basic functions of gamification: increasing the effectiveness of learning, direction of human behavior, overcoming barriers, solving life situations, and achieving goals through play. N. Volkova (Volkova, 2018) paid attention to the use of game mechanics in non-game situations to encourage certain behavior (gamification) and organizational and methodological approaches to their use in higher education. V. Bugaieva (Bugaieva, 2017) considers the impact of gamification on the training and competitiveness of specialists in the field of IT. The author confirms the expediency of using gamification in education to increase motivation and activity, the active professional position development of future professionals. O. Makarevych (Makarevych, 2015) considers the advantages of using gamification directly in distance learning. The author proves the effectiveness of this tool, as learning in the form of a game increases the motivation to learn, facilitates the assimilation of material, improves orientation in the learning management system. O. Pasichnyk's (Pasichnyk, 2018) research is devoted to gamification as a promising innovative tool for improving the language competence of high school students remotely, individually, and during classroom work. Integration possibilities of various educational platforms (DuoLingo, Content Generator, Moodle, Jeopardy Labs) into educational process for creation on their basis of interactive professionally-oriented games, quests, and quizzes are considered. L. Sergeeva (Sergeeva, 2014) analyzes the publications of foreign authors, in particular, M. Barber (Barber, 1996), A. Faria (Faria, 2009), D. Clark (Clark, 2011), L. Sheldon (Sheldon, 2011), etc. in which it is proved that gamification increases motivation to work, and the use of game mechanics helps to improve communication quality in the team, identify leaders, reduce the number of conflicts, increase the overall level of productivity, encourage students to learn.

The purpose of the article is to analyze the use of gamification mechanisms to improve the training of future librarians.

Presentation of main material. This study is devoted to gamification as an innovative tool for training future librarians, able to stimulate cognitive and educational activities and influence their activity in the learning process. Gamification is the process of using game thinking and game dynamics to 
engage audiences and solve problems. The term "gamification" first appeared in 1912, when the famous company "Cracker" began to put a surprise toy in its products, which later became popular among other companies. Gamification gained real popularity only in 2010 thanks to examples that demonstrated the nature and effectiveness of this phenomenon, and was integrated into numerous structures, including the education system, and was presented to a wide audience. It should be noted that gamification is suitable for any learning process and does not require large financial investments. This toolmethod allows you to overcome all stages of the work process and involve staff and future professionals in the implementation of the team game, which will achieve great success in realizing the practical potential of the participants in the process. With the help of gamification, libraries will be able to improve communication between employees, thereby introducing a corporate culture to find the necessary information and involve future professionals to realize themselves in the profession of a librarian. Modern training conditions in the era of pandemic and quarantine restrictions, allowed to apply gamification in the conditions of remote learning and to determine its effectiveness in the course of practical research. It was attended by students of 029 "Information, Library and Archival Affairs" of KhAI, 50 students ( $\mathrm{m}=17, \mathrm{f}=33$ ). Students underwent internships at the University Library of KhAI. The library staff had a task to improve the professional level of students during a pandemic and to develop their desire for self-study at the workplace. Gamification has become a basic tool in the process of this training. The staff of the library together with the teachers of the department developed a questionnaire in Google Forms, which was filled out by all students who had an internship. The questionnaire contained the following questions.

1. Indicate the groups in which you study.

2. Specify your age.

3. Specify your gender.

4. Do you like to play games?

5. Have you played role games in your specialty while studying at the institute?

6. What game have you recently played? What games do you prefer (strategies, RPGs, shooters, etc.)

7. What professional topics are you interested in?

8. How often do you play games?

9. Why do you play games?

10. If modern companies used corporate games, would you consider it an advantage? Explain your answer.

After all, students answered the questionnaire, the results were analyzed.

It turned out that $85 \%$ of students play games every day, $47 \%$ of them like 
to play strategies, $32 \%$ play RPGs, and the rest in shooters, races, puzzles. The question "why do you play" was answered as follows: "when I play, I am distracted and I am visited by fresh ideas for my self-realization"; "in the game, I rest and switch to another activity"; "the game helps me relax and not think about current problems"; "I just love to play" and so on.

It was decided to introduce this tool in the training of future librarians and to develop a bilateral project between the department and the library based on the positive assessment of the gamification respondents. For this purpose the technical task was registered, technical possibilities were analyzed, platforms for training were chosen. Technical and analytical group were formed. The analytical group formed several stages of the learning process, based on the basic rules of gamification. The mission of this corporate student game was defined. The mission was to set a time frame for achieving a result and a way to implement it. The next stage was the introduction of a realistic picture of the world (perception), which allowed us to take definite actions to achieve the result. An important stage for the project was to work with university psychologists, who analyzed the psychological characteristics of students, described the psychotypes, and gave relevant peaces of advice in organizing the psychological basis of the game, to motivate participants in this project: to work with digital interfaces, quizzes, corporate holidays to encourage and motivate target audience.

Conclusions. As a result, the pilot project passed all stages of implementation, the tasks of improving the level of knowledge were achieved and the corporate culture of the library staff and students was strengthened. We concluded that library staff needs to be involved in such projects to diversify the learning process with new technologies that make the workflow efficient. For students who plan to become librarians in the future, this game helps to immerse themselves in the atmosphere of the library, to understand the basic principles and mechanisms of work. Also, gamification must be positioned as an effective learning factor that will help not only to involve students into the profession, but also to motivate employees for further career growth.

\section{References}

Buhaieva, V. (2017). Gamification as a way of forming active professional behavior of future IT professionals. Pedagogika ta psihologija, 56, 129-135. [In Ukrainian].

Didiakova, O. (2018). Game as a tool: what is gamification? Mistosite. Retrieved from https://mistosite.org.ua/ru/articles/hra-iak-instrument-shcho-takeheimifikatsiia. [In Ukrainian].

Kravets, N. (2017). Stages of creating a gamified system for use in the educational process of higher education. Visnyk Kharkivskoi derzhavnoi akademii kultury. Seriia: Sotsialni komunikatsii, 50, 198-206. [In Ukrainian]. 
Makarevch, O. (2015). Gamification as an integral factor in improving the effectiveness of remote learning elements. Molodyi naukovets, 2, 279-282. [In Ukrainian].

Pasichnyk, O. (2018). Gamification of the process of learning a foreign language by students of higher education institutions. Pedagogichna osvita: teorija $i$ praktika, 24 (2), 344-349. [In Ukrainian].

Sergeeva, L. (2014). Gamification: game mechanics in staff motivation. Theory and methods of educational management. Retrieved from http://umo. edu.ua/images/content/nashi_vydanya/metod_upr_osvit/v_15/14.pdf. [In Ukrainian].

Volkova, N. (2018). Information and communication technologies. Gamification Interactive learning technologies in higher education. Teaching method way. Dnipro: Universite Alfred Nobel. [In Ukrainian].

Barber, M. (1996). The Learning Game: Arguments for an Educational Revolution. London: Victor Gollancz. [In English].

Clark, D. (2011). Games and e-Learning. Retrieved from http://www.caspianlearning. co.uk/Whtp-caspian-games-1.1.pdf. [In English].

Faria, A. J. (2009). Developments in Business Gaming. A Review of the Past 40 Years. (pp. 464-487). Rochester: Rochester Institute of Technology. [In English].

Sheldon, L. (2011). The Multiplayer Classroom: Designing Coursework as a Game. Course Technology PTR, Florence, KY. [In English].

Надійшла до редколегії 22.03.2021 